\title{
The Influence of Vitamin A Supplementation on Foxp3 and TGF- $\beta$ Gene Expression in Atherosclerotic Patients
}

\author{
Azadeh Mottaghi $^{\mathrm{b}}$ Eisa Salehic ${ }^{\mathrm{c}}$ Ali Keshvarz $^{\mathrm{b}}$ \\ Hashem Sezavar ${ }^{d}$ Ali-Akbar Saboor-Yaraghi ${ }^{a, b}$ \\ a Department of Cellular and Molecular Nutrition, School of Nutrition and Dietetics, \\ ${ }^{b}$ Department of Nutrition and Biochemistry, School of Public Health, ${ }^{C}$ Department of \\ Immunology, Faculty of Medicine, and d Division of Cardiology, Department of Internal \\ Medicine, School of Medicine, Tehran University of Medical Sciences, Tehran, Iran
}

\author{
Key Words \\ Foxp3 $\cdot$ TGF- $\beta \cdot$ Atherosclerosis $\cdot$ Gene expression
}

\begin{abstract}
The aim of this study was to investigate the role of vitamin A in Foxp3 and TGF- $\beta$ gene expression in atherosclerotic patients. Patients and healthy controls in the vitamin A group received 25,000 IU retinyl palmitate per day, while patients in the placebo group took one capsule of placebo per day for 4 months. Gene expressions of regulatory T cells were studied by real-time PCR. The levels of Foxp3 expression in phytohemagglutinin-activated cells were much higher in the patients who received vitamin A than in placebo-treated patients and healthy controls, while Foxp3 gene expression in oxidized low-density lipoprotein-activated cells showed no significant differences between all groups $(p=0.357)$. A significant difference in the expression level of TGF- $\beta$ gene in fresh cells was observed between patients and healthy controls $(p=0.009)$. TGF- $\beta$ gene expression in oxidized low-density lipoprotein-activated cells increased in all groups; however, these changes were not statistically significant $(p=0.65)$; the changes obtained were 2.8-, 2.2- and 3.9-fold in the vitamin A, placebo, and control groups, respectively. Based on suppressing actions of regulatory $T$ cells on effector $T$ cells and findings that show that vitamin $A$ has the effect of increasing expression of regulatory $T$ cells, it can be concluded that supplementation with vitamin $A$ in atherosclerotic patients may be effective in slowing disease progression.




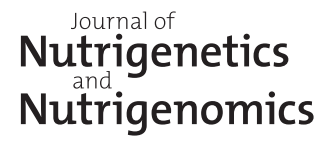

\begin{tabular}{|c|c|}
\hline \multicolumn{2}{|c|}{ J Nutrigenet Nutrigenomics 2012;5:314-326 } \\
\hline $\begin{array}{l}\text { DOI: } 10.1159 / 000341916 \\
\text { Published online: January 26, } 2013\end{array}$ & $\begin{array}{l}\text { ( ) } 2013 \text { S. Karger AG, Basel } \\
\text { www.karger.com/jnn }\end{array}$ \\
\hline
\end{tabular}

Mottaghi et al.: The Influence of Vitamin
Expression in Atherosclerotic Patients

\section{Introduction}

Cardiovascular disease is a main cause of mortality in the eastern Mediterranean area that includes Iran [1]. Atherosclerosis is a chronic inflammation of the arterial wall that involves $\mathrm{T}$ lymphocytes and where both innate and adaptive immune responses participate in the initiation and progression of the disease [2]. The role of T lymphocytes in human atherosclerotic plaque has been recognized for nearly two decades [3]. Pathogenic T cells distinguish between auto-antigens including low-density lipoprotein (LDL), and modified oxidized LDL (ox-LDL) and similarly between normal and modified heat shock protein-60 (HSP-60). The aggregation of inflammatory cells within the arterial wall leads to production of cytokines that increase the influx of monocytes and lymphocytes, thereby enhancing the progression of atherosclerotic lesions [2].

Regulatory $\mathrm{T}$ (Treg) cells are a subset of CD4+ T cells that express forkhead box protein-3 (Foxp3) [4]. Treg cells play a pivotal role in the regulation of T cell-mediated immune responses through suppression of $\mathrm{T}$ cell proliferation, release of anti-inflammatory cytokines [interleukin (IL)-10 and transforming growth factor (TGF)- $\beta$ ] [5], mediation of selftolerance, and prevention of autoimmune diseases [6]. Foxp3 is a master transcription factor for Tregs and a requisite factor for the development and suppressive actions of Tregs, since no suppressive function was observed in CD4+CD25+ isolated from Foxp3 knockout mice [7-9]. Treg cells are generated in two distinct manners: in the thymus upon contact with selfantigen (natural Treg, nTreg) and in the peripheral immune compartment (induced Treg, iTreg) [4]. nTreg cells produce TGF- $\beta$ and iTreg cells produce IL-10 [8].

Consistent with the hypothesis that atherosclerotic plaque inflammation is partly related to autoimmunity, likely by ox-LDL, a role of Treg cells in atherosclerosis and plaque formation could be expected [10]. The protective role of CD4+CD25+Foxp3+ Treg cells in the development of plaque in atherosclerosis has been shown in previous studies [11-13]. Treg cells have a potential suppressive effect on the in situ inflammatory response [10]. Indeed, Mor et al. [14] have recently shown that the number of Treg cells in the peripheral blood of patients with acute coronary syndrome is decreased. It has recently been shown that when the number of Treg cells in atherosclerosis-prone (ApoE-/-) mice increased, the size of atherosclerotic lesions shrinked $[11,13]$.

Foxp3 - naïve T cells are activated by antigen-presenting cells, such as dendritic cells, and mature into Foxp3 + T cells; however, some environmental factors, such as cytokines milieu and retinoids, can influence this maturation [15]. Retinoic acid (RA) is an active metabolite of vitamin A that plays an important role in the immune system. RA can suppress autoimmune reactions by promoting the conversion of naïve T cells into iTreg cells [4]. In humans, RA has been thought to induce the histone acetylation at the Foxp3 promoter and enhance its transcription [15]. TGF- $\beta$ is an important cytokine to induction of Foxp3 expression and RA has been shown to act as a cofactor that enhances TGF- $\beta$-mediated induction of CD4+ and CD8+Foxp3+ T cells $[15,16]$.

In an attempt to find how vitamin A may affect Treg gene expression, the present study was designed to investigate the role of vitamin A supplementation on Treg gene expression under different activation conditions.

\section{Materials and Methods}

Patients

Thirty-one atherosclerotic patients ( 16 men and 15 women, aged $38-69$ years; mean age 56 years) and 15 healthy controls ( 8 men and 7 women, aged $39-62$ years; mean age 56.5 years) were enrolled in this study. Presence of atherosclerosis in patients was diagnosed by coronary angiography; all patients enrolled 
Table 1. Primer sequences for real-time PCR

\begin{tabular}{llll}
\hline Gene & Sequence & Amplicon size, bp \\
\hline TGF- $\beta$ & $\begin{array}{l}\text { Forward: } \\
\text { Reverse: }\end{array}$ & $5^{\prime}$-CTCTCCGACCTGCCACAGA-3' & 72 \\
\hline FOXP3 & Forward: & $5^{\prime}$-GCAAAGTTGTTTTTGATACGTGACA-3' & 77 \\
& Reverse: & $5^{\prime}$-AGGCTTGGTGAAGTGGACTGA-3' & \\
\hline$\beta$-Actin & Forward: & $5^{\prime}$-CCTGGCACCCAGCACAAT-3' & 70 \\
& Reverse: & $5^{\prime}$-GCCGATCCACACGGAGTACT-3' & \\
\hline
\end{tabular}

were divided into two randomly allocated groups (vitamin A or placebo) by random permuted blocks within the strata (age and sex) method. All patients were on aspirin and statin treatment. None of the patients and healthy controls had any other diseases, such as asthma, active virus disease, rheumatoid arthritis, systemic lupus, multiple sclerosis, type 1 diabetes, and inflammatory bowel disease, or were on medication that would have an effect on the immune system, such as corticosteroids or immunosuppressive drugs. Patients and healthy controls in the vitamin A group received 25,000 IU of retinyl palmitate per day. Patients and healthy controls in the placebo group took one capsule of placebo per day for 4 months. For all participants, a food frequency questionnaire at the beginning and end of the study was filled out. All patients gave written informed consent to participate in this study, which was approved by the ethical committee of Tehran University of Medical Sciences.

\section{Peripheral Blood Mononuclear Cell Isolation and Cell Culture}

Peripheral blood mononuclear cells (PBMCs) were isolated from heparinized peripheral blood by standard Ficoll-Hypaque (Sigma-Aldrich, St. Louis, Mo., USA) density-gradient centrifugation. It was then suspended in RPMI 1640 medium (Gibco; Invitrogen; Paisley, UK) supplemented with 10\% heat-inactivated fetal calf serum (Gibco; Invitrogen) and $100 \mathrm{U} / \mathrm{ml}$ penicillin/streptomycin (Sigma) at a concentration of $1 \times 10^{6}$ cells per ml.

Plasma was obtained after 10 min centrifugation at $400 \mathrm{~g}$ and transferred into tubes where it was stored at $-80^{\circ} \mathrm{C}$ in order to measure lipid profile. $4 \times 10^{6}$ cells were put away for RNA extraction, and the remaining cells were cultured in 24-well culture plates at a density of $1 \times 10^{6}$ cells per well with $\mathrm{T}$ cell activator, phytohemagglutinin (PHA; Sigma), at a final concentration of $10 \mu \mathrm{g} / \mathrm{ml}$, with $2 \mu \mathrm{g} / \mathrm{ml}$ specific antigen, ox-LDL (Biomedical Technology Inc, Mass., USA), and the other group of cells without any stimulation. PBMCs were incubated in a humidified atmosphere with $5 \% \mathrm{CO}_{2}$ at $37^{\circ} \mathrm{C}$ for $72 \mathrm{~h}$. Next, supernatants of cell culture were harvested and frozen at $-80^{\circ} \mathrm{C}$ for other biochemical assays, and subsequently, all of the cells that settled in the plate were collected for RNA extraction.

\section{RNA Extraction and cDNA Synthesis}

Cytoplasmic RNA was extracted and purified using RNeasy Plus Mini Kit (Qiagen, Valencia, Calif., USA) according to the manufacturer's protocol. Quantity and purity of extracted RNA was checked by NanoDrop spectrophotometer (NanoDrop Technologies, Wilmington, Del., USA). A ratio of A 260/280 between 1.9-2.1 was taken into account as pure RNA. Single-strand cDNA was synthesized using QuantiTect Reverse Transcription Kit (Qiagen).

\section{Real-Time Polymerase Chain Reaction for Gene Expression}

Real-time polymerase chain reaction (PCR) was carried out in StepOne system (Applied Biosystems, Foster City, Calif., USA) with SYBR Green detection method. PCR primers for TGF- $\beta$, IL-10, Foxp3 genes and $\beta$-actin gene (as housekeeping) were designed by Primer Express 3 software (Applied Biosystems) and purchased from Metabion (table 1). The PCR reactions were performed as follows: PCR proceeded in special optical tubes in 48-well reaction plates (MicroAmp Optical, ABI, Foster City, Calif., USA) with $20 \mu \mathrm{l}$ reaction mixture containing $10 \mu$ l Power SYBR Green PCR Master Mix (Applied Biosystems), $7 \mu$ l DEPCtreated water, $0.5 \mu \mathrm{l}$ forward primer, $0.5 \mu \mathrm{l}$ reverse primer, and $2 \mu \mathrm{l} \mathrm{cDNA}$ as template. The wells were sealed with optical adhesive film (Applied Biosystems), and the plate was centrifuged for several seconds at high speed. Amplification conditions were performed using the standard two-step run protocol: step 
Table 2. Clinical data of patients and healthy controls

\begin{tabular}{lccl}
\hline Characteristics & Healthy controls & Patients & p value \\
\hline Age, years & $53 \pm 7$ & $55 \pm 7$ & 0.292 \\
Sex, male/female & $5 / 7$ & $16 / 15$ & \\
Body mass index & $28.6 \pm 4.6$ & $29.7 \pm 4.0$ & 0.434 \\
Waist-to-hip ratio & $0.89 \pm 0.1$ & $0.91 \pm 0.1$ & 0.577 \\
Abdomen circumference, cm & $94.17 \pm 8.3$ & $101.13 \pm 7.4$ & 0.01 \\
Total vitamin A intake, RE/day & $224.83 \pm 67.09$ & $254.39 \pm 85.67$ & 0.290 \\
\hline
\end{tabular}

All values are expressed as means $\pm \mathrm{SD}$ or numbers. $\mathrm{RE}=$ Retinol equivalent.

$1,10 \mathrm{~s}$ at $95^{\circ} \mathrm{C}$; step 2,40 cycles of $15 \mathrm{~s}$ at $95^{\circ} \mathrm{C}$ plus $1 \mathrm{~s}$ at $60^{\circ} \mathrm{C}$. After completion of PCR amplification cycles, melt curve was generated to verify that a single gene product had been amplified.

For each gene, mRNA expression level was normalized to the level of $\beta$-actin mRNA. The fold changes of genes expression were computed using the comparative $\mathrm{Ct}\left(2^{-\Delta \Delta \mathrm{Ct}}\right)$ method.

\section{Statistical Analysis}

Two groups of patients and the control group were analyzed, with independent-sample $t$ test and paired-sample $t$ test done for comparison of the results within the groups. Statistical differences between different conditions were evaluated by one-way ANOVA, followed by post hoc Scheffé test. In those conditions where the assumption of homogeneity of variances had been violated, the Welch test was used instead of one-way ANOVA. Qualitative data were analyzed by the Kruskal-Wallis test. Normality of all data was checked by Kolmogorov-Smirnov test. A p value $<0.5$ was considered statistically significant. Analyses were performed by SPSS 16 (SPSS, Inc., Chicago, Ill., USA).

\section{Results}

\section{Basic Characteristics of Patients}

Demographic and clinical characteristics of patients and healthy controls are illustrated in table 2 . As we can see, there were no statistically significant differences in age, sex, body mass index, and total vitamin A intake among patients and healthy controls. However, values of abdomen circumference in patients were found to be significantly higher than in healthy controls.

\section{FOXP3 and TGF- $\beta$ Expression in Fresh Cell-Extracted $m R N A$}

Results of this study show that expression of Foxp3 mRNA in the patient groups and healthy controls had statistically significant differences $(\mathrm{p}=0.0001$, fig. 4-6). Vitamin Atreated patients had 10.1-fold increases $(\mathrm{p}=0.0001)$ in FOXP3 gene expression, but patients who received placebo showed 1.9 -fold increases $(\mathrm{p}=0.254)$ in FOXP3 gene expression. Healthy controls also showed 5.6-fold increases $(\mathrm{p}=0.0001)$ in FOXP3 gene expression. As to the relative gene expression of TGF- $\beta$, a significant difference in the expression level of this gene was observed between patient groups and healthy controls $(\mathrm{p}=0.009)$. Patients who took vitamin $A$, the placebo group and healthy controls showed a 4.6- $(\mathrm{p}=0.001), 1.7-(\mathrm{p}=$ $0.373)$, and 2.9-fold $(\mathrm{p}=0.002)$ increase, respectively (fig. 1; tables 3,4$)$.

\section{FOXP3 and TGF- $\beta$ Expression in PHA-Activated Cell-Extracted mRNA}

The Kruskal-Wallis test showed statistically significant differences between groups $(\mathrm{p}=$ 0.009 , fig. 4-6). The levels of FOXP3 expression were much higher in the patients that re- 
Nutrigenetics

Nutrigenomics

Fig. 1. Fold changes of FOXP3 and TGF- $\beta$ expression in fresh PBMCs after supplementation. Box plot with whiskers displays the interquartile range. The bottom box (lower quartile) and top box (upper quartile) represent the 25th and 75th percentile, respectively. The median value is represented by the horizontal line in the box.

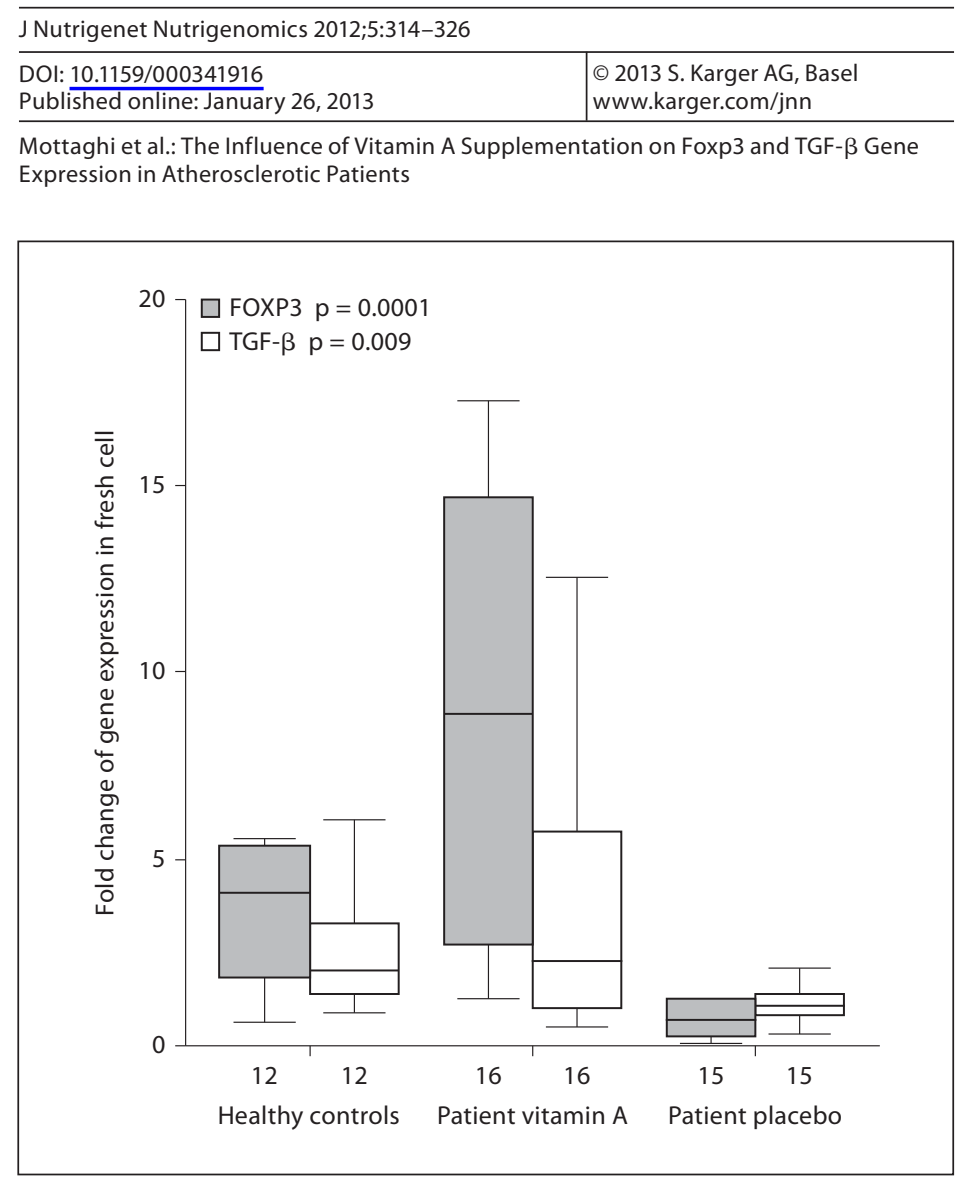

Table 3. $\Delta \mathrm{CT}$ and mean of TGF- $\beta$ gene expression in fresh cells

\begin{tabular}{|c|c|c|c|c|c|}
\hline & & \multicolumn{2}{|l|}{ Patient group } & \multirow{2}{*}{$\begin{array}{l}\text { Control group } \\
(\mathrm{n}=12)\end{array}$} & \multirow[t]{2}{*}{$\mathrm{p}$ value } \\
\hline & & $\operatorname{vitamin} A(n=16)$ & placebo $(\mathrm{n}=15)$ & & \\
\hline \multirow{4}{*}{$\begin{array}{l}\Delta \mathrm{CT} \text { of TGF- } \beta \\
\text { in fresh cells }\end{array}$} & Before & $10.96 \pm 1.76$ & $10.45 \pm 1.72$ & $8.20 \pm 1.98$ & 0.001 \\
\hline & After & $9.37 \pm 2.13$ & $10.20 \pm 1.92$ & $7.03 \pm 2.02$ & 0.001 \\
\hline & Difference & $-1.59 \pm 1.46$ & $-0.25 \pm 1.06$ & $-1.17 \pm 1.03$ & $0.013^{\mathrm{c}}$ \\
\hline & $\mathrm{p}$ value ${ }^{\mathrm{b}}$ & 0.001 & 0.373 & 0.002 & \\
\hline \multicolumn{2}{|c|}{ Mean of TGF- $\beta$ gene expression in fresh cells } & $4.61 \pm 4.11$ & $1.67 \pm 2.04$ & $2.96 \pm 2.73$ & $0.009^{c}$ \\
\hline
\end{tabular}

Data are reported as means $\pm \mathrm{SD} . \Delta \mathrm{CT}=\mathrm{CT}$ of target gene $-\mathrm{CT}$ of $\beta$-actin.

a One-way ANOVA. ${ }^{b}$ Paired-sample $t$ test. ${ }^{c}$ Kruskal-Wallis test.

Table 4. $\triangle \mathrm{CT}$ and mean of FOXP3 gene expression in fresh cells

\begin{tabular}{|c|c|c|c|c|c|}
\hline & & \multicolumn{2}{|l|}{ Patient group } & \multirow{2}{*}{$\begin{array}{l}\text { Control group } \\
(\mathrm{n}=12)\end{array}$} & \multirow[t]{2}{*}{$\mathrm{p}$ value $\mathrm{a}^{\mathrm{a}}$} \\
\hline & & $\operatorname{vitamin} A(n=16)$ & placebo $(n=15)$ & & \\
\hline \multirow{4}{*}{$\begin{array}{l}\Delta \mathrm{CT} \text { of FOXP3 } \\
\text { in fresh cells }\end{array}$} & Before & $12.92 \pm 1.40$ & $10.49 \pm 1.63$ & $11.57 \pm 0.91$ & 0.0001 \\
\hline & After & $10.20 \pm 1.68$ & $11.12 \pm 1.21$ & $9.67 \pm 1.02$ & 0.027 \\
\hline & Difference & $-2.72 \pm 1.33$ & $0.62 \pm 2.04$ & $-1.90 \pm 1.16$ & $0.0001^{\mathrm{c}}$ \\
\hline & $\mathrm{p}$ value $\mathrm{e}^{\mathrm{b}}$ & 0.0001 & 0.254 & 0.0001 & \\
\hline \multicolumn{2}{|c|}{ Mean of FOXP3 gene expression in fresh cells } & $10.09 \pm 8.70$ & $1.93 \pm 3.17$ & $5.58 \pm 6.09$ & $0.0001^{c}$ \\
\hline
\end{tabular}

Data are reported as means $\pm \mathrm{SD} . \Delta \mathrm{CT}=\mathrm{CT}$ of target gene $-\mathrm{CT}$ of $\beta$-actin.

a One-way ANOVA. ${ }^{\mathrm{b}}$ Paired-sample t test. ${ }^{\mathrm{c}}$ Kruskal-Wallis test. 


\section{Journal of
Nutrigenetics Nutrigenomics}

Fig. 2. Fold changes of FOXP3 and TGF- $\beta$ expression in PHAactivated PBMCs after supplementation. Box plot with whiskers displays the interquartile range. The bottom box (lower quartile) and top box (upper quartile) represent the 25th and 75 th percentile, respectively. The median value is represented by the horizontal line in the box.

\begin{tabular}{l}
\hline \begin{tabular}{l} 
J Nutrigenet Nutrigenomics 2012;5:314-326 \\
\hline $\begin{array}{l}\text { DOI: 10.1159/000341916 } \\
\text { Published online: January 26, 2013 }\end{array}$
\end{tabular} \\
\hline $\begin{array}{l}\text { Mottaghi et al.: The Influence of Vitamin A Supplementation on Foxp3 and TGF- } \beta \text { Gene } \\
\text { Expression in Atherosclerotic Patients }\end{array}$
\end{tabular}

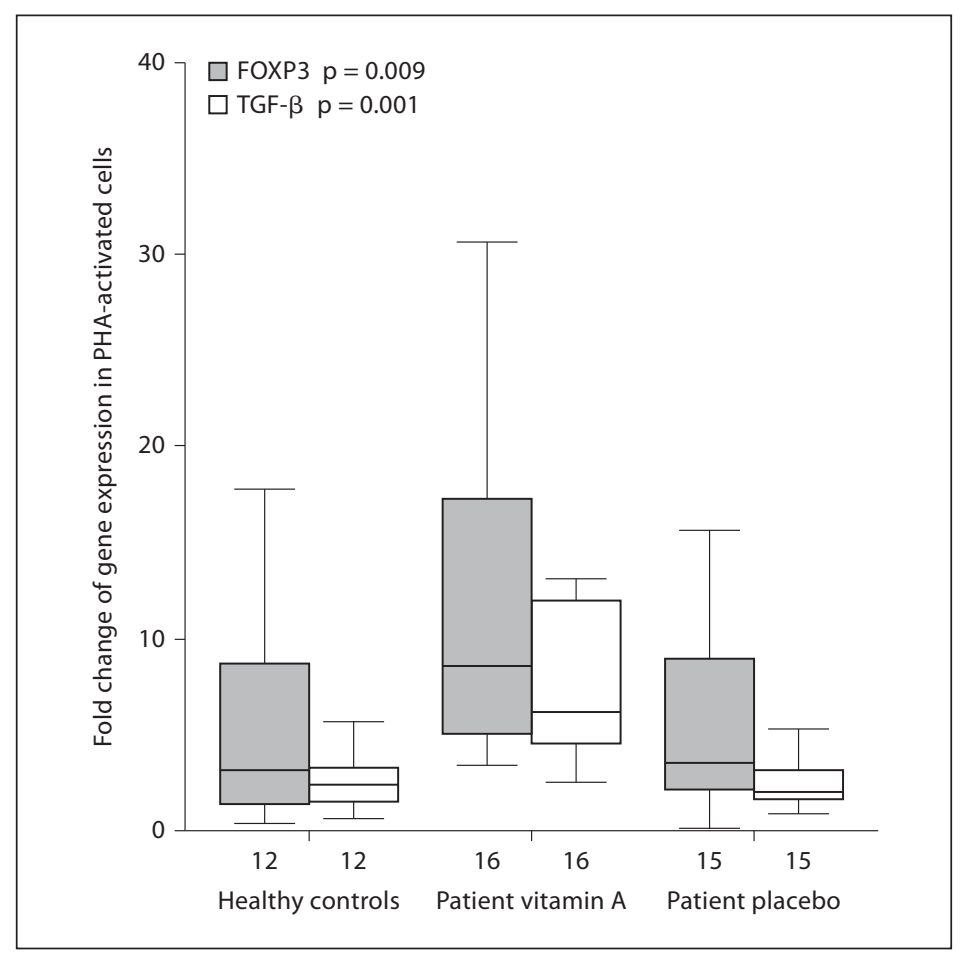

Table 5. $\Delta \mathrm{CT}$ and mean of TGF- $\beta$ gene expression in PHA-activated cells

\begin{tabular}{|c|c|c|c|c|c|}
\hline & & \multicolumn{2}{|l|}{ Patient group } & \multirow{2}{*}{$\begin{array}{l}\text { Control group } \\
(\mathrm{n}=12)\end{array}$} & \multirow[t]{2}{*}{$\mathrm{p}$ value ${ }^{\mathrm{a}}$} \\
\hline & & vitamin $A(n=16)$ & placebo $(n=15)$ & & \\
\hline \multirow{4}{*}{$\begin{array}{l}\Delta \mathrm{CT} \text { of TGF- } \beta \text { in } \\
\text { PHA-activated cells }\end{array}$} & Before & $13.15 \pm 1.20$ & $13.05 \pm 1.83$ & $13.88 \pm 0.85$ & 0.261 \\
\hline & After & $10.29 \pm 1.49$ & $11.79 \pm 1.70$ & $12.13 \pm 1.16$ & 0.004 \\
\hline & Difference & $2.86 \pm 1.03$ & $1.27 \pm 1.09$ & $1.75 \pm 1.25$ & $0.001^{\mathrm{c}}$ \\
\hline & $\mathrm{p}$ value $\mathrm{e}^{\mathrm{b}}$ & 0.0001 & 0.001 & 0.001 & \\
\hline \multicolumn{2}{|c|}{ Mean of TGF- $\beta$ gene expression in PHA-activated cells } & $9.39 \pm 7.94$ & $3.38 \pm 3.94$ & $4.84 \pm 4.97$ & $0.001^{\mathrm{c}}$ \\
\hline
\end{tabular}

Data are reported as means $\pm \mathrm{SD} . \Delta \mathrm{CT}=\mathrm{CT}$ of target gene $-\mathrm{CT}$ of $\beta$-actin.

a One-way ANOVA. ${ }^{\mathrm{b}}$ Paired-sample t test. ${ }^{\mathrm{c}}$ Kruskal-Wallis test.

ceived vitamin A (13.9-fold increase; $\mathrm{p}=0.0001)$ compared to those receiving a placebo (5.6fold increase; $p=0.002$ ) and healthy controls (7.6-fold increase; $p=0.009)$. Multiple comparisons between groups showed that this significant difference was related to a difference between vitamin A-treated patients and placebo-treated patients. The relative TGF- $\beta$ gene expression in PHA-activated cells collected from patients in the vitamin A, placebo, and healthy control groups was determined. TGF- $\beta$ mRNA expression of vitamin A-treated patients showed a 9.4-fold $(\mathrm{p}=0.0001)$ increase, while those patients in the placebo group and healthy controls slightly increased by 3.4- $(\mathrm{p}=0.001)$ and 4.8 -fold $(\mathrm{p}=0.001)$, respectively $(\mathrm{p}=0.001)$. The difference between vitamin $\mathrm{A}$ and placebo groups was significant $(\mathrm{p}=0.02$; fig. 2; tables 5, 6). 
Table 6. $\triangle \mathrm{CT}$ and mean of FOXP3 gene expression in PHA-activated cells

\begin{tabular}{|c|c|c|c|c|c|}
\hline & & Patient group & & Control group & $\mathrm{p}$ value $\mathrm{a}^{\mathrm{a}}$ \\
\hline & & $\operatorname{vitamin} \mathrm{A}(\mathrm{n}=16)$ & placebo $(n=15)$ & & \\
\hline$\Delta \mathrm{CT}$ of FOXP3 in & Before & $16.54 \pm 1.34$ & $14.51 \pm 3.14$ & $14.24 \pm 1.46$ & 0.012 \\
\hline PHA-activated cells & After & $13.22 \pm 1.46$ & $12.74 \pm 2.11$ & $12.47 \pm 1.45$ & 0.504 \\
\hline & Difference & $-3.32 \pm 1.18$ & $-1.77 \pm 1.81$ & $-1.77 \pm 1.96$ & $0.019^{c}$ \\
\hline & $\mathrm{p}$ value $\mathrm{b}^{\mathrm{b}}$ & 0.0001 & 0.002 & 0.009 & \\
\hline Mean of FOXP3 gen & expression in PHA-activated cells & $13.90 \pm 12.82$ & $5.61 \pm 5.02$ & $7.60 \pm 10.94$ & $0.009^{c}$ \\
\hline
\end{tabular}

Data are reported as means $\pm \mathrm{SD} . \Delta \mathrm{CT}=\mathrm{CT}$ of target gene $-\mathrm{CT}$ of $\beta$-actin.

${ }^{a}$ One-way ANOVA. ${ }^{b}$ Paired-sample $t$ test. ${ }^{c}$ Kruskal-Wallis test.

\section{FOXP3 and TGF- $\beta$ Expression in ox-LDL-Activated Cell-Extracted $m R N A$}

The expression levels of FOXP3 mRNA in ox-LDL-activated PBMCs obtained from vitamin A-treated patients, placebo-treated patients, and healthy controls were measured. The results showed no significant differences between all groups $(\mathrm{p}=0.357$, fig. $4-6)$, but the level of FOXP3 expression in patients who took vitamin A was higher than in the placebotreated patients: there was a 4.0- $(\mathrm{p}=0.203), 3.2-(\mathrm{p}=0.357)$, and 5.4-fold $(\mathrm{p}=0.009)$ increase in the vitamin A group, placebo group, and healthy controls, respectively. In order to determine whether ox-LDL stimulation of PBMCs in vitro had an effect on TGF- $\beta$ expression, we measured the difference between patients who took vitamin A, placebo-treated patients, and healthy controls. The TGF- $\beta$ levels increased in all groups, but the differences between the groups were not statistically significant $(\mathrm{p}=0.65)$; the changes obtained were $2.8-(\mathrm{p}=0.140)$, 2.2 - $(\mathrm{p}=0.028)$, and 3.9-fold $(\mathrm{p}=0.041)$ in the vitamin $\mathrm{A}$, placebo, and control groups, respectively (fig. 3 ; tables 7,8 ).

\section{Discussion}

In the current study, 31 patients and 12 healthy controls underwent a 4-month-long supplementation program of vitamin A or placebo in order to determine the effect of vitamin A supplementation on gene expression of cytokines secreted by Treg cells and their transcription factors.

In many inflammatory diseases such as atherosclerosis, Treg cells have an important role in the attenuation of inflammation. This anti-inflammatory mechanism functions through secretion of anti-inflammatory cytokines such as IL-10 and TGF- $\beta$. Treg cells, as in the case of FOXP3+ T cells, can downregulate the immune system via suppression of overactive responses, inflammation caused by other T cells, and downstream of non-T effector cells [15].

Vitamin A and its active metabolites including all-trans RA (ATRA) and 9-cis RA (9-cis RA) play important roles in the immune system; they are involved in immune cell differentiation and maintaining immune homeostasis. For example, vitamin A and its metabolites can reduce inflammatory conditions in certain diseases such as type 1 diabetes [17], rheumatoid arthritis [18], atherosclerosis [19], and experimental encephalomyelitis [20].

Our results showed a 10.1-fold increase in FOXP3 expression in fresh PBMCs obtained from patients who were treated with vitamin $\mathrm{A}$, whereas this increase in placebo patients was only 1.9-fold. Healthy controls also showed a statistically significant increase in FOXP3 expression. 


\section{Journal of
Nutrigenetics Nutrigenomics}

Fig. 3. Fold changes of FOXP3 and TGF- $\beta$ expression in oxLDL-activated PBMCs after supplementation. Box plot with whiskers displays the interquartile range. The bottom box (lower quartile) and top box (upper quartile) represent the 25 th and 75 th percentile, respectively. The median value is represented by the horizontal line in the box.

\begin{tabular}{l|l}
\hline J Nutrigenet Nutrigenomics 2012;5:314-326 \\
\hline $\begin{array}{l}\text { DOI: 10.1159/000341916 } \\
\text { Published online: January 26, } 2013\end{array}$ & $\begin{array}{l}\text { @ 2013 S. Karger AG, Basel } \\
\text { www.karger.com/jnn }\end{array}$ \\
\hline $\begin{array}{l}\text { Mottaghi et al.: The Influence of Vitamin A Supplementation on Foxp3 and TGF- } \beta \text { Gene } \\
\text { Expression in Atherosclerotic Patients }\end{array}$
\end{tabular}

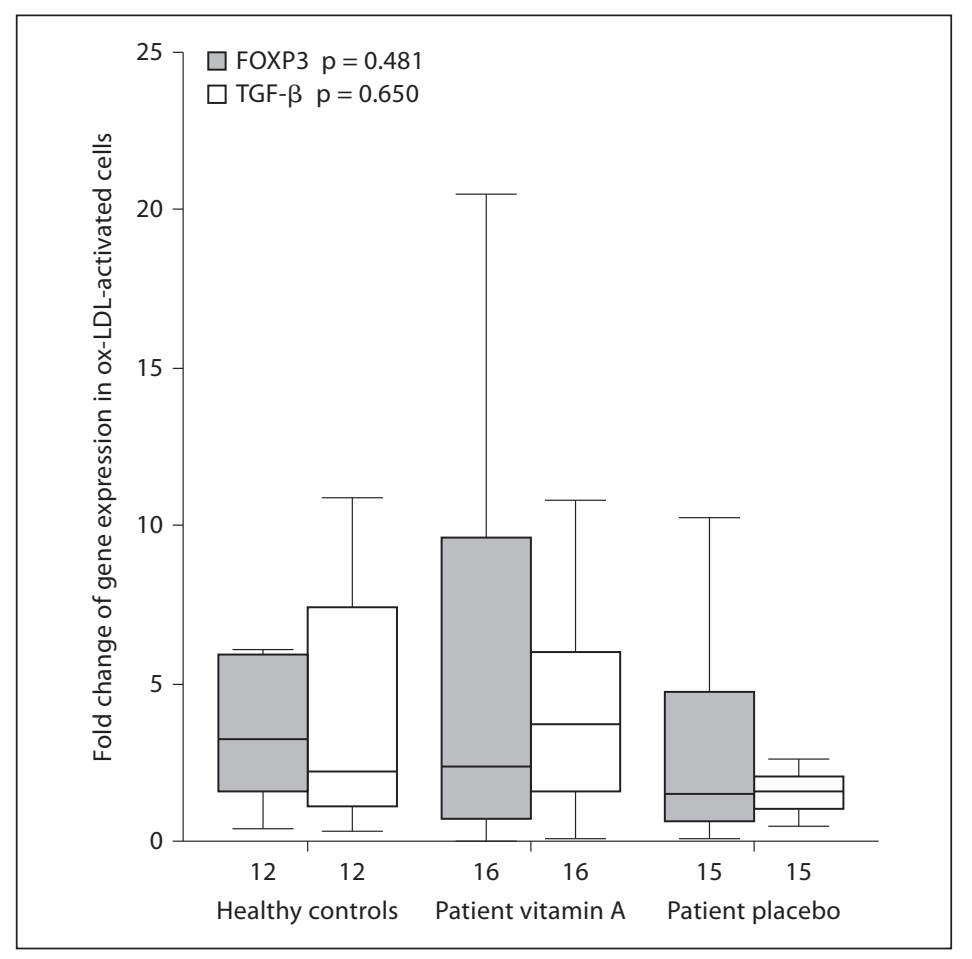

Table 7. $\Delta \mathrm{CT}$ and mean of TGF- $\beta$ gene expression in ox-LDL-activated cells

\begin{tabular}{|c|c|c|c|c|c|}
\hline & & \multicolumn{2}{|l|}{ Patient group } & \multirow{2}{*}{$\begin{array}{l}\text { Control } \\
\text { group } \\
(\mathrm{n}=12)\end{array}$} & \multirow[t]{2}{*}{$\mathrm{p}$ value } \\
\hline & & vitamin $A(n=16)$ & placebo $(n=15)$ & & \\
\hline \multirow{4}{*}{$\begin{array}{l}\Delta \mathrm{CT} \text { of TGF- } \beta \text { in } \\
\text { ox-LDL activated cells }\end{array}$} & Before & $5.41 \pm 0.97$ & $4.65 \pm 0.59$ & $5.00 \pm 0.71$ & 0.035 \\
\hline & After & $4.70 \pm 1.64$ & $3.97 \pm 1.18$ & $3.85 \pm 1.48$ & 0.233 \\
\hline & Difference & $0.70 \pm 1.81$ & $0.68 \pm 1.08$ & $1.15 \pm 1.73$ & $0.691^{\mathrm{c}}$ \\
\hline & $\mathrm{p}$ value $\mathrm{b}^{\mathrm{b}}$ & 0.140 & 0.028 & 0.041 & \\
\hline \multicolumn{2}{|c|}{ Mean of TGF- $\beta$ gene expression in ox-LDL-activated cells } & $2.76 \pm 2.43$ & $2.17 \pm 2.10$ & $3.92 \pm 3.96$ & $0.650^{\mathrm{c}}$ \\
\hline
\end{tabular}

Data are reported as means $\pm \mathrm{SD} . \Delta \mathrm{CT}=\mathrm{CT}$ of target gene $-\mathrm{CT}$ of $\beta$-actin.

${ }^{a}$ One-way ANOVA. ${ }^{b}$ Paired-sample t test. ${ }^{c}$ Kruskal-Wallis test.

Table 8. $\triangle \mathrm{CT}$ and mean of FOXP3 gene expression in ox-LDL-activated cells

\begin{tabular}{|c|c|c|c|c|c|}
\hline & & \multicolumn{2}{|l|}{ Patient group } & \multirow{2}{*}{$\begin{array}{l}\text { Control } \\
\text { group } \\
(\mathrm{n}=12)\end{array}$} & \multirow[t]{2}{*}{$\mathrm{p}$ value $\mathrm{a}^{\mathrm{a}}$} \\
\hline & & $\operatorname{vitamin} A(n=16)$ & placebo $(n=15)$ & & \\
\hline \multirow{4}{*}{$\begin{array}{l}\Delta \mathrm{CT} \text { of FOXP3 in } \\
\text { ox-LDL activated cells }\end{array}$} & Before & $13.27 \pm 2.06$ & $12.85 \pm 1.25$ & $12.99 \pm 1.03$ & 0.750 \\
\hline & After & $12.32 \pm 1.67$ & $12.29 \pm 1.87$ & $11.34 \pm 1.37$ & 0.255 \\
\hline & Difference & $-0.95 \pm 2.86$ & $-0.57 \pm 2.33$ & $-1.64 \pm 1.78$ & $0.523^{\mathrm{c}}$ \\
\hline & $\mathrm{p}$ value $\mathrm{b}^{\mathrm{b}}$ & 0.203 & 0.357 & 0.009 & \\
\hline \multicolumn{2}{|c|}{ Mean of FOXP3 gene expression in ox-LDL-activated cells } & $6.88 \pm 10.73$ & $3.92 \pm 5.13$ & $5.90 \pm 7.14$ & $0.481^{\mathrm{c}}$ \\
\hline
\end{tabular}

Data are reported as means $\pm \mathrm{SD} . \Delta \mathrm{CT}=\mathrm{CT}$ of target gene $-\mathrm{CT}$ of $\beta$-actin.

${ }^{\text {a }}$ One-way ANOVA. ${ }^{\text {b }}$ Paired-sample $t$ test. ${ }^{c}$ Kruskal-Wallis test. 
Journal of

Nutrigenetics

Nutrigenomics
J Nutrigenet Nutrigenomics 2012;5:314-326

\begin{tabular}{l|l}
\hline DOI: $10.1159 / 000341916$ & (c) 2013 S. Karger AG, Basel
\end{tabular}

Published online: January 26, 2013

www.karger.com/jnn

322
Fig. 4. Fold changes of FOXP3 and TGF- $\beta$ expression in patients receiving vitamin $\mathrm{A}$ after supplementation. Box plot with whiskers displays the interquartile range. The bottom box (lower quartile) and top box (upper quartile) represent the 25 th and 75 th percentile, respectively. The median value is represented by the horizontal line in the box.
Mottaghi et al.: The Influence of Vitamin A Supplementation on Foxp3 and TGF- $\beta$ Gene Expression in Atherosclerotic Patients

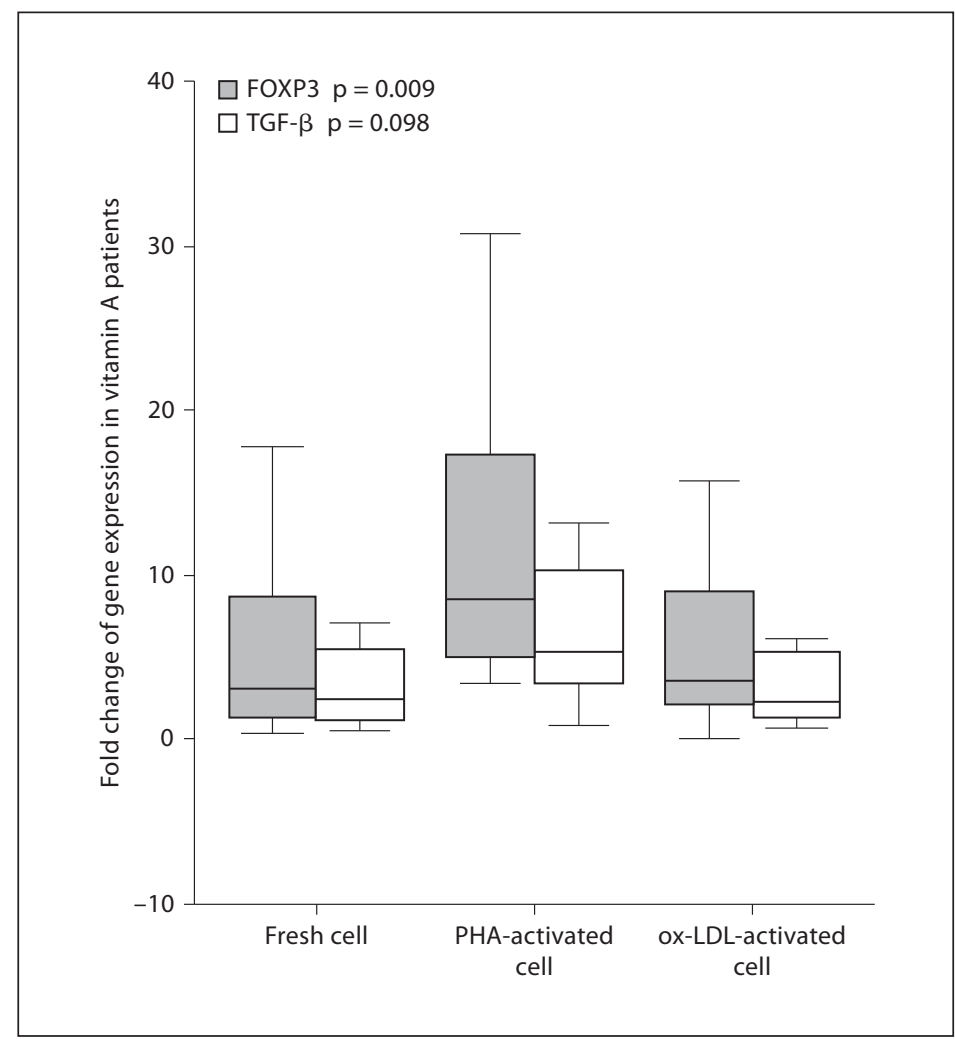

Some studies have shown that RA regulates induction of FOXP3 CD4+ T cells in the periphery [7, 21-26]. Schambach et al. [26] showed that ATRA induces FOXP3 and diverts cells toward the Treg lineage and away from the Th17 lineage. RA via retinoid X receptor- $\alpha$ (RXR- $\alpha$ ) can modulate expression of FOXP3 and inhibition of Th17 polarization [27].

In a study by Kang et al. [7], human naïve CD4+CD25- T cells that contained $>99.9 \%$ FoxP3-CD4+ were isolated from neonatal cord blood and cultured in the presence or absence of ATRA. Results indicated that FoxP3- T cells that were cultured with ATRA had a higher expression of FoxP3 mRNA in comparison with T cells cultured without ATRA. These findings are in agreement with results obtained in this paper.

In the present study, it was demonstrated that retinyl palmitate supplementation increases TGF- $\beta$ gene expression in fresh PBMCs of patients who received vitamin A relative to all other groups. These findings indicate that increase in TGF- $\beta$ gene expression via vitamin $\mathrm{A}$ is indirectly controlled by various mechanisms involving different receptors. Kishi et al. [28] and Uchida et al. [29] showed that in the retinal pigment epithelial cells, RA increased production of TGF- $\beta$, but MacDonald et al. [30] demonstrated that RA can reduce expression of TGF- $\beta$ at both protein and mRNA levels. Many studies have shown that RA is an important factor in inducing the production of FoxP3+ cells in the gut and peripheral lymphoid tissues $[15,21,22]$. TGF- $\beta$, a cytokine that is secreted from FoxP3+ T cells, has anti-inflammatory and atherosclerotic plaque-stabilizing effects [31,32]. Their stabilizing effects are applied through induction of extracellular matrix synthesis [2]. It is not clear how ATRA enhances gene expression of FoxP3, but some evidence suggests that this increase is related to histone acetylation in the FoxP3 promoter region through RAR $\alpha$ [34].

To investigate the effect of various stimuli on regulation of gene expression by vitamin A, we cultured PBMCs of patients and healthy controls with the general T-cell mitogen, PHA, and specific antigen, ox-LDL. 


\section{Journal of \\ Nutrigenetics \\ Nutrigenomics}

Fig. 5. Fold changes of FOXP3 and TGF- $\beta$ expression in patients receiving placebo after supplementation. Box plot with whiskers displays the interquartile range. The bottom box (lower quartile) and top box (upper quartile) represent the 25th and 75th percentile, respectively. The median value is represented by the horizontal line in the box.
Jutrigenet Nutrigenomics 2012;5:314-326

DOI: $10.1159 / 000341916$

(c) 2013 S. Karger AG, Basel

Published online: January 26, 2013

www.karger.com/jnn

323

Mottaghi et al.: The Influence of Vitamin A Supplementation on Foxp3 and TGF- $\beta$ Gene Expression in Atherosclerotic Patients

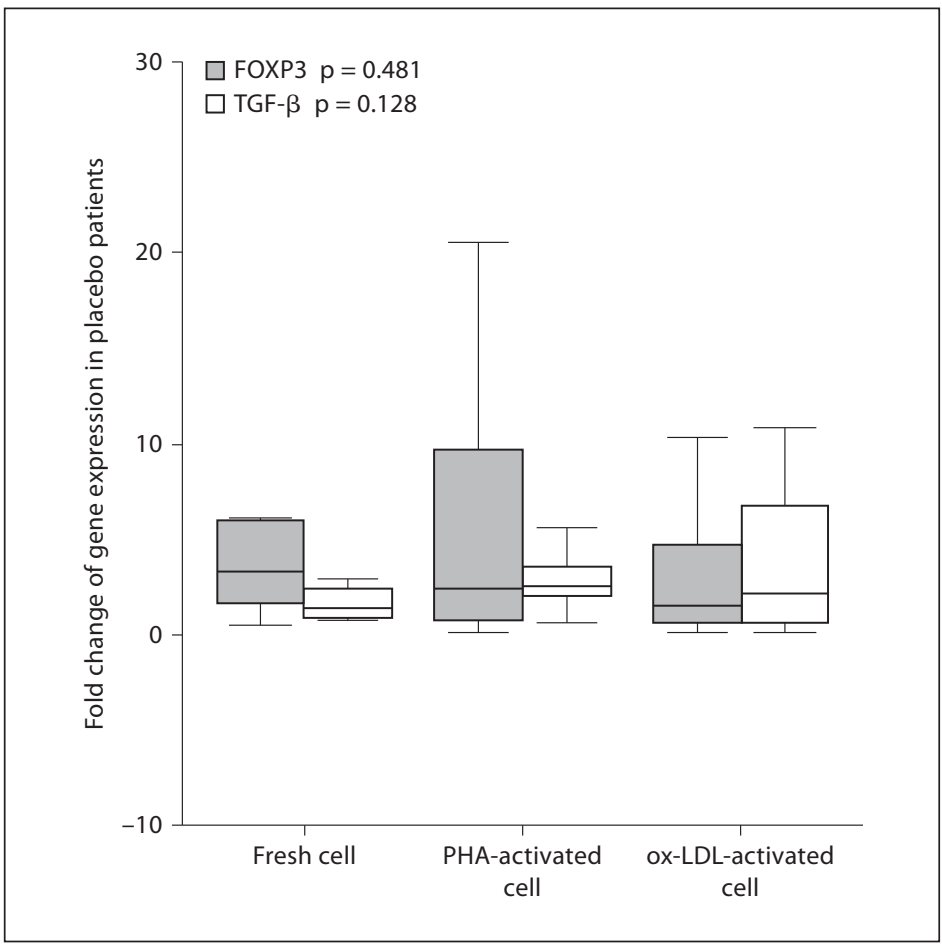

Fig. 6. Fold changes of FOXP3 and TGF- $\beta$ expression in healthy controls after supplementation. Box plot with whiskers displays the interquartile range. The bottom box (lower quartile) and top box (upper quartile) represent the 25 th and 75 th percentile, respectively. The median value is represented by the horizontal line in the box.

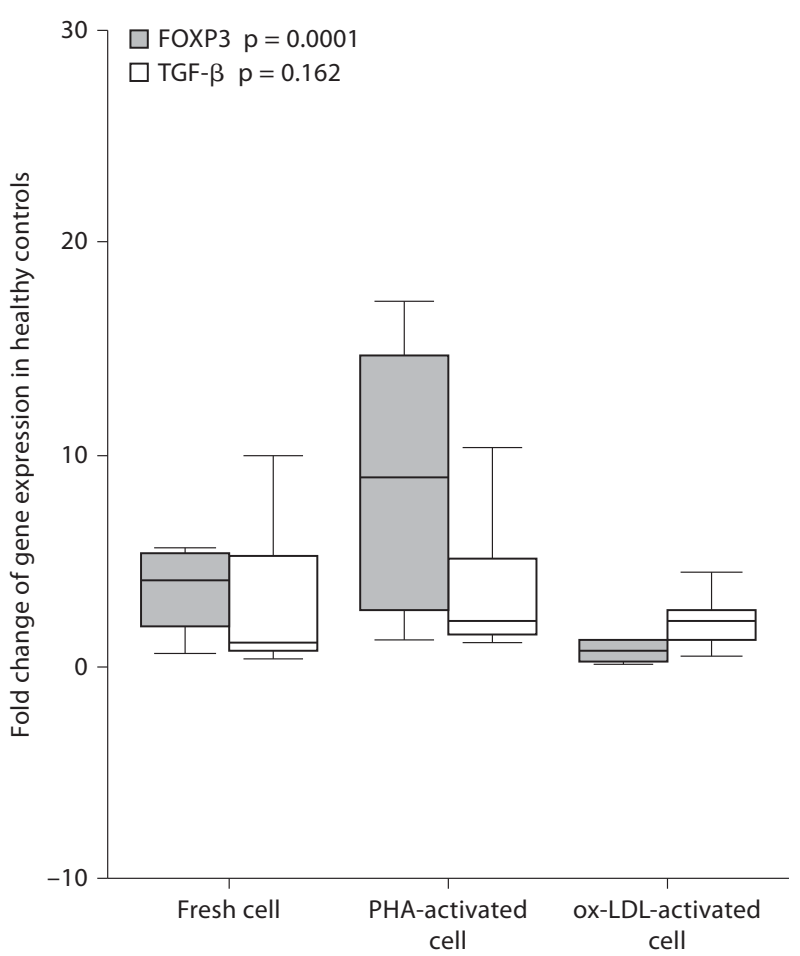


PHA-activated cells in patients who had received vitamin A showed higher rates of FOXP3 and TGF- $\beta$ expression than cells of placebo-treated patients and healthy controls.

$\mathrm{PHA}$ is a T-cell mitogen which requires a functional T-cell receptor complex such as CD3 that mimics antigenic stimulation of T cells in order to be activated. It seems that many of the effects induced by PHA have the function to cross-link CD3 molecules on T cells. Likely effects of PHA on FOXP3 and TGF- $\beta$ expression may be mediated through CD3 signaling. It has been shown that ATRA enhances induction of FOXP3 expression by activation of CD3 and CD28 [7]. In accordance with our results, Kang et al. [7] showed that desired induction of FoxP3+ T cells induced by retinoid required activation through co-stimulation by antiCD3 and anti-CD28. Signals from CD28 activation can increase generation of FoxP3+ T cells induced by retinoids.

Results of a study by Wang et al. [35] showed that when THP-1 monocyte cell line was stimulated by lipopolysaccharide (LPS) at different concentration levels $(1,10$, and $100 \mathrm{ng} /$ $\mathrm{ml}$ ) and $10^{-6} \mathrm{M}$ ATRA, the expression of IL-10 mRNA was increased 2.2- to 5.6-fold compared with LPS alone. These results contradict findings in the same study which revealed no detectable change in the mRNA expression levels of TGF- $\beta$ in cultures containing ATRA even when cultures were stimulated with LPS. Wang et al. [36] showed that $1-25 \mu \mathrm{g} / \mathrm{ml}$ PHA was effective in increasing the expression of FOXP3.

In a study conducted by Xiao et al. [4], naïve CD4+ cells were activated by anti-CD28 and anti-CD3 plus RA with TGF- $\beta$ and RA alone. Results of this study showed that when cells were cultured with RA alone, no Foxp3 expression was seen, but when RA along with TGF- $\beta$ was added to the culture medium, 78\% of cells expressed Foxp3. This finding is inconsistent with our results.

The results of this study show that the levels of FOXP3 and TGF- $\beta$ gene expression in PBMCs which were stimulated with ox-LDL in both groups of patients were lower than in healthy controls, although the gene expression in vitamin A-treated patients was slightly higher than in placebo-administered patients. Decreased gene expression of FOXP3 and TGF- $\beta$ in patients may be attributed to the fact that those suffering from atherosclerosis have higher levels of ox-LDL in their cells, and addition of extra stimulation with ox-LDL in vitro can cause cell death and eventually reduce total gene expression. However, with regard to results that show gene expression in vitamin A-treated patients that is slightly higher than in placebo patients, it can be said that vitamin A was able to partially prevent apoptotic effects of ox-LDL on cells. Autoanti-ox-LDL antibodies and activated T lymphocytes against ox-LDL have been detected in the serum of atherosclerotic patients [37,38]. In line with the results of our study, Mor et al. [14] observed that in Treg cells obtained from patients with acute coronary syndrome that were cultured with $1 \mu \mathrm{g} / \mathrm{ml}$ ox-LDL, ox-LDL reduced Treg levels by $40 \pm 8 \%$; they also showed that FoxP3 expression was significantly reduced $(68 \%)$ in Treg cells of patients with acute coronary syndrome in comparison with people with normal coronary arteries. Lower levels of gene expression in patients may reflect the sensitivity of Tregs to ox-LDL. If in these links a cause and effect relationship is to be considered, it could be concluded that lower numbers of Tregs due to increased sensitivity can cause augmentation of plaque inflammation and destabilization and rupture in atherosclerotic patients. Many studies also confirmed low numbers of FoxP3+ Treg cells and decreased FoxP3 expression due to ox-LDL exposure $[10,13,39]$. It is not unexpected that vitamin A due to its proliferative roles can prevent the destructive and apoptotic effects of ox-LDL on T lymphocytes. It has been shown that responses of $\mathrm{T}$ cells, such as level of mRNA synthesis, can be inhibited by ox-LDL. This inhibition could be related to an alteration in the homeostatic regulation of normal intracellular $\mathrm{T}$ cell response signals. The inhibitory effect of ox-LDL on T cells may be due to ox-LDL increasing the concentration of reactive oxygen intermediates. These intermediates can cause an oxidative shift in the sig- 
nal redox state, thereby leading to modification in the nature of the stimulatory signal, thus resulting in cell cycle arrest [40].

One of the limitations of this study was isolation of T cells from the PBMC population; therefore, more acceptable results would be obtained if isolated T cells were used.

\section{Conclusion}

To our knowledge, this is the first clinical trial of the effects of vitamin A supplementation on Foxp3 and TGF- $\beta$ gene expression in atherosclerotic patients. Many studies have shown that ATRA can lead to an increase in Foxp3 and TGF- $\beta$ gene expression and the number of Treg cells, and several studies have pointed to the fact that vitamin A supplementation causes elevated levels of ATRA and 9-Cis RA in blood; we have postulated that these cells may also be increased through supplementation with vitamin A. Due to the anti-inflammatory and plaque-stabilizing effect of TGF- $\beta$ and suppressing actions of Treg cells on effector $T$ cells that are present in atherosclerotic plaque, and also vitamin A effects on increases in number of Treg cells, it can be concluded that supplementation with vitamin A in patients with atherosclerosis may be effective in slowing disease progression.

\section{Acknowledgments}

This study was supported by a grant from Tehran University of Medical Sciences (89-01-27-10471). The contributions of the personnel who work at the Department of Nutrition and Biochemistry, School of Public Health, Tehran University of Medical Sciences, are sincerely appreciated. We would like to acknowledge the kind assistance of all patients and control subjects.

\section{References}

1 Meraji S, Abuja PM, Hayn M, Kostner GM, Morris R, Oraii S, Tatzber F, Wonisch W, Zechner R, Gey KF: Relationship between classic risk factors, plasma antioxidants and indicators of oxidant stress in angina pectoris (AP) in Tehran. Atherosclerosis 2000;150:403-412.

2 Ait-Oufella H, Taleb S, Mallat Z, Tedgui A: Cytokine network and T cell immunity in atherosclerosis. Semin Immunopathol 2009;31:23-33.

-3 Gotsman I, Gupta R, Lichtman AH: The influence of the regulatory T lymphocytes on atherosclerosis. Arterioscler Thromb Vasc Biol 2007;27:2493-2495.

- Xiao S, Jin H, Korn T, Liu SM, Oukka M, Lim B, Kuchroo VK: Retinoic acid increases Foxp3+ regulatory T cells and inhibits development of Th17 cells by enhancing TGF-beta-driven Smad3 signaling and inhibiting IL-6 and IL-23 receptor expression. J Immunol 2008;181:2277-2284.

5 Cheng X, Yu X, Ding YJ, Fu QQ, Xie JJ, Tang TT, Yao R, Chen Y, Liao YH: The Th17/Treg imbalance in patients with acute coronary syndrome. Clin Immunol 2008;127:89-97.

6 Guyot-Revol V, Innes JA, Hackforth S, Hinks T, Lalvani A: Regulatory T cells are expanded in blood and disease sites in patients with tuberculosis. Am J Respir Crit Care Med 2006;173:803-810.

7 Kang SG, Lim HW, Andrisani OM, Broxmeyer HE, Kim CH: Vitamin A metabolites induce gut-homing Foxp3+ regulatory T cells. J Immunol 2007;179:3724-3733.

$\checkmark 8$ George J: Mechanisms of disease: the evolving role of regulatory T cells in atherosclerosis. Nat Clin Pract Cardiovasc Med 2008;5:531-540.

-9 Fontenot JD, Gavin MA, Rudensky AY: Foxp3 programs the development and function of CD4+CD25+ regulatory T cells. Nat Immunol 2003;4:330-336.

$\longrightarrow 10$ de Boer OJ, van der Meer JJ, Teeling P, van der Loos CM, van der Wal AC: Low numbers of Foxp3 positive regulatory $\mathrm{T}$ cells are present in all developmental stages of human atherosclerotic lesions. PLoS One 2007;2:e779.

$\checkmark 11$ Ait-Oufella H, Salomon BL, Potteaux S, Robertson AK, Gourdy P, Zoll J, Merval R, Esposito B, Cohen JL, Fisson S, Flavell RA, Hansson GK, Klatzmann D, Tedgui A, Mallat Z: Natural regulatory T cells control the development of atherosclerosis in mice. Nat Med 2006;12:178-180. 


\section{Nutrigenetics Nutrigenomics}

\begin{tabular}{l|l|}
\hline J Nutrigenet Nutrigenomics 2012;5:314-326 \\
\hline DOI: 10.1159/000341916 & $\begin{array}{l}\text { @ } 2013 \text { S. Karger AG, Basel } \\
\text { www.karger.com/jnn }\end{array}$ \\
\hline Published online: January 26, 2013 &
\end{tabular}

Mottaghi et al.: The Influence of Vitamin A Supplementation on Foxp3 and TGF- $\beta$ Gene Expression in Atherosclerotic Patients

12 Mallat Z, Ait-Oufella H, Tedgui A: Regulatory T cell responses: potential role in the control of atherosclerosis. Curr Opin Lipidol 2005; 16:518-524.

$\checkmark 13$ Mor A, Planer D, Luboshits G, Afek A, Metzger S, Chajek-Shaul T, Keren G, George J: Role of naturally occurring CD4+ CD25+ regulatory T cells in experimental atherosclerosis. Arterioscler Thromb Vasc Biol 2007;27:893-900.

14 Mor A, Luboshits G, Planer D, Keren G, George J: Altered status of CD4(+)CD25(+) regulatory T cells in patients with acute coronary syndromes. Eur Heart J 2006;27:2530-2537. Kim CH: Regulation of FoxP3 regulatory T cells and Th17 cells by retinoids. Clin Dev Immunol 2008;2008:416910. Maynard CL, Hatton RD, Helms WS, Oliver JR, Stephensen CB, Weaver CT: Contrasting roles for all-trans retinoic acid in TGF-beta-mediated induction of Foxp3 and IL10 genes in developing regulatory T cells. J Exp Med 2009;206: 343-357.

17 Zunino SJ, Storms DH, Stephensen CB: Diets rich in polyphenols and vitamin A inhibit the development of type I autoimmune diabetes in nonobese diabetic mice. J Nutr 2007;137:1216-1221.

18 Miyagawa N, Homma T, Kagechika H, Shudo K, Nagai H: Effect of synthetic retinoid, TAC-101, on experimental autoimmune disease. Pharmacology 2003;67:21-31.

19 Rhee EJ, Nallamshetty S, Plutzky J: Retinoid metabolism and its effects on the vasculature. Biochim Biophys Acta 2011; 1821:230-240.

20 Racke MK, Burnett D, Pak SH, Albert PS, Cannella B, Raine CS, McFarlin DE, Scott DE: Retinoid treatment of experimental allergic encephalomyelitis. IL-4 production correlates with improved disease course. J Immunol 1995;154: $450-458$.

$>2$ Elias KM, Laurence A, Davidson TS, Stephens G, Kanno Y, Shevach EM, O’Shea JJ: Retinoic acid inhibits Th17 polarization and enhances Foxp3 expression through a Stat-3/Stat-5 independent signaling pathway. Blood 2008;111:10131020.

Mucida D, Park Y, Kim G, Turovskaya O, Scott I, Kronenberg M, Cheroutre H: Reciprocal Th17 and regulatory T cell differentiation mediated by retinoic acid. Science 2007;317:256-260.

23 Benson MJ, Pino-Lagos K, Rosemblatt M, Noelle RJ: All-trans retinoic acid mediates enhanced Treg cell growth, differentiation, and gut homing in the face of high levels of co-stimulation. J Exp Med 2007;204:1765-1774.

-24 Sun CM, Hall JA, Blank RB, Bouladoux N, Oukka M, Mora JR, Belkaid Y: Small intestine lamina propria dendritic cells promote de novo generation of Foxp3 T reg cells via retinoic acid. J Exp Med 2007;204:1775-1785.

25 Coombes JL, Siddiqui KR, Arancibia-Carcamo CV, Hall J, Sun CM, Belkaid Y, Powrie F: A functionally specialized population of mucosal CD103+ DCs induces Foxp3+ regulatory T cells via a TGF-beta and retinoic acid-dependent mechanism. J Exp Med 2007;204:1757-1764.

26 Schambach F, Schupp M, Lazar MA, Reiner SL: Activation of retinoic acid receptor-alpha favours regulatory T cell induction at the expense of IL-17-secreting T helper cell differentiation. Eur J Immunol 2007;37:2396-2399.

27 Bai A, Lu N, Guo Y, Liu Z, Chen J, Peng Z: All-trans retinoic acid down-regulates inflammatory responses by shifting the Treg/Th17 profile in human ulcerative and murine colitis. J Leukoc Biol 2009;86:959-969.

28 Kishi H, Kuroda E, Mishima HK, Yamashita U: Role of TGF-beta in the retinoic acid-induced inhibition of proliferation and melanin synthesis in chick retinal pigment epithelial cells in vitro. Cell Biol Int 2001;25:1125-1129.

-29 Uchida H, Kuroki M, Shitama T, Hayashi H, Kuroki M: Activation of TGF-beta1 through up-regulation of TSP-1 by retinoic acid in retinal pigment epithelial cells. Curr Eye Res 2008;33:199-203.

-30 MacDonald IM, Pannu R, Kovithavongs K, Peters C, Tredget EE, Ghahary A: Effect of retinoic acid on expression of transforming growth factor-beta by retinal pigment epithelial cells in culture. Can J Ophthalmol 1995;30:301-305.

-31 Mallat Z, Gojova A, Marchiol-Fournigault C, Esposito B, Kamate C, Merval R, Fradelizi D, Tedgui A: Inhibition of transforming growth factor-beta signaling accelerates atherosclerosis and induces an unstable plaque phenotype in mice. Circ Res 2001;89:930-934.

-32 Lutgens E, Gijbels M, Smook M, Heeringa P, Gotwals P, Koteliansky VE, Daemen MJ: Transforming growth factorbeta mediates balance between inflammation and fibrosis during plaque progression. Arterioscler Thromb Vasc Biol 2002;22:975-982.

-33 Grainger DJ, Mosedale DE, Metcalfe JC, Bottinger EP: Dietary fat and reduced levels of TGFbetal act synergistically to promote activation of the vascular endothelium and formation of lipid lesions. J Cell Sci 2000;113:2355-2361.

34 Jenuwein T, Allis CD: Translating the histone code. Science 2001;293:1074-1080.

35 Wang X, Allen C, Ballow M: Retinoic acid enhances the production of IL-10 while reducing the synthesis of IL-12 and TNF-alpha from LPS-stimulated monocytes/macrophages. J Clin Immunol 2007;27:193-200.

-36 Wang T, Monte MM, Huang W, Boudinot P, Martin SA, Secombes CJ: Identification of two Foxp3 genes in rainbow trout (oncorhynchus mykiss) with differential induction patterns. Mol Immunol 2010;47:2563-2574.

-37 Matsuura E, Kobayashi K, Tabuchi M, Lopez LR: Oxidative modification of low-density lipoprotein and immune regulation of atherosclerosis. Prog Lipid Res 2006;45:466-486.

38 Hansson GK, Libby P, Schonbeck U, Yan ZQ: Innate and adaptive immunity in the pathogenesis of atherosclerosis. Circ Res 2002;91:281-291.

-39 Fortun A, Khalil A, Gagne D, Douziech N, Kuntz C, Jay-Gerin JP, Dupuis G, Fulop T Jr: Monocytes influence the fate of $\mathrm{T}$ cells challenged with oxidised low density lipoproteins towards apoptosis or MHC-restricted proliferation. Atherosclerosis 2001;156:11-21.

-40 Caspar-Bauguil S, Saadawi M, Negre-Salvayre A, Thomsen M, Salvayre R, Benoist H: Mildly oxidized low-density lipoproteins suppress the proliferation of activated CD4+ T-lymphocytes and their interleukin 2 receptor expression in vitro. Biochem J 1998;330:659-666. 